\title{
Redd barna
}

\section{I riksvåpenet ved inngangen til Barneombudet er løven erstattet av en teddybjørn. Barnelegen Lindboe bruker kløkt, sjarm og faglighet for å hjelpe barn, særlig de som har det verst.}

Hun er tilgjengelig gjennom en e-postkasse hvor det er presisert at henvendelser fra barn blir prioritert. Barneombudet er en stor bedrift der Anne Lindboe er administrerende direktør, men der det også finnes ekspertgrupper - for eksempel et rådgivende barne- og ungdomspanel. Intervjuet gjennomføres uten at en medierådgiver sitter i en krok og følger med. Det er kanskje en tillitserklæring.

Barneombudet holder til i nedre del av Karl Johan. Lokalene er store og lyse. Det er et offentlig kontor, men med grafittivegg, leker, lufthockeyspill og små, gjennomsiktige barneklistremerker på glassdørene til møterommene. I alle intervjuene da hun startet i jobben ble det trukket frem at mannen tok henne med på handletur i London. Han syntes hun hadde troppet opp i den grå «rettssakkyndigjakken» $\mathrm{i}$ for mange intervjuer på rad. Nå er hun stilsikker, blå blazer og silkeskjerf gir assosiasjoner til næringslivet snarere enn rettssal og helsevesen. Lindboe ser opplagt ut. Vi har siste avtale fredag ettermiddag - før det blir helg. I alle intervjuer blir det lange, lyse håret og det gode humøret trukket frem. Er det mulig å være så blid bestandig?

- Det skal jo ikke gå utover andre at du er trett eller sliten på jobben. Man legger inn et ekstra gir og tar seg sammen. Slik er det jo når man jobber på sykehus også. Som helsearbeider kan du ikke vise at du har en dårlig dag når du møter pasienter.

\section{Det ubegripelige}

Hun vil gjerne snakke til legene om det som ikke er bra. Lindbo kommer fort inn på sak og sosialpediatri, hun vil gripe sjansen til å nå frem til flere kolleger og fortelle om noe som er så ubegripelig og forferdelig at det er vanskelig å fatte.

- Hjemmet er det farligste stedet for barn, slår hun fast. - Det er jo ikke i trafikken eller i barnehagen de er mest utsatt. Når du ser et barnetog, kan du tenke gjennom at to av hundre utsettes for grov vold. Ti av hundre barn lider under en form for omsorgssvikt. Foreldre ruser seg eller har psykiske problemer - og barna lider i stillhet.

Lindboe har jobbet på sosialpediatrisk seksjon og kjenner bedre enn de fleste til «hjemmets skumle vrede». Der treffer de barn som er utsatt for vold og overgrep og har alvorlige spiseforstyrrelser. På Retts- medisinsk institutt har hun deltatt i obduksjoner der barnet har ikke har overlevd omsorgssvikten. Det har opprørt henne at disse barna ikke har noen som taler deres sak. Det er litt av grunnen til at jobben som barneombud fristet.

- Sosialpediatri er et nedprioritert område. Det har lav prestisje hos oss leger. Barn får stort sett god hjelp i helsevesenet. På områder som kreft og hjertesykdom er det stor faglig kompetanse og mye forskning. Det er et tankekors at det er mange flere barn som opplever vold enn det er barn som blir rammet av kreft, men ressursene står ikke i forhold. Helsepersonell må bli bedre til å varsle når vi har grunn til å tro at barn ikke får den omsorgen de trenger. - Hvorfor er disse barna nedprioritert?

- Kanskje er voldelige forhold blitt oppfattet som en del av privatlivets sfære og vi har vært redde for å blande oss borti det.

\section{«Hjemmet er det farligste stedet for barn»}

Kanskje er det manglende evne til å fatte hvor grusomme foreldre kan være mot barn. Barn som blir slått, har ingen pressgrupper som jobber for dem.

- Hvorfor melder vi for sjelden fra til barnevernet?

- Det skyldes nok dels mangel på kunnskap, dels at man er redd for å ta feil og dels at vi stikker hodet i sanden og ikke vil tro at noen faktisk skader barn.

Hun snakker om mulig enda fortere og samtidig tydeligere. - «Grunn til å tro», det er det hele. Vi trenger ikke vite at det er omsorgssvikt eller vold. Ved «grunn til å tro» skal vi melde fra, uten å la oss hindre av taushetsplikten.

Hun vil hamre budskapet inn i hodet på alle leger: - Vi må ikke være feige når det handler om barn.

\section{Lykkelige øyeblikk}

- Hva har du lært av å jobbe med utsatte barn?
- Jeg vet altfor godt at ikke alle foreldre er gode foreldre. Samtidig har jeg sett hvordan små grep kan gjøre stor forskjell. Jeg har fătt oppleve å være en som virkelig ser barnet. Det er fantastisk å møte barn som har fătt det bedre. Det er lite som kan måle seg med det når det gjelder lykkelige øyeblikk på jobben.

- Hva var vanskelig?

- Det verste var saker hvor det var usikkert om barnet ble trodd. Kanskje ville barnet komme hjem til samme situasjon, bare med erfaringen av at å fortelle om det vanskelige ikke hjalp og i frykt for å bli straffet for det.

Hun vil ikke bare male fanden på veggen. - Det skjer mye positivt nå. Kristoffer-saken har gjort noe med folks bevissthet rundt overgrep. På flere barneavdelinger satses det nå på dette feltet, og det er på høy tid. - Hvordan er det å være lege og barneombud?

- Jeg har nok med meg en prioritering i ryggmargen - jeg synes det er viktigst å hjelpe de barna som har det verst. Det er for så vidt barn opptatt av også, de har en utpreget rettferdighetssans.

Barn liker Anne Lindboe. Interessen er gjensidig.

- Jeg synes barn er interessante. Barn har meninger. I høst skal vi ut på veien med «barneombussen». Vi skal besøke skoler og informere barn om oss og om deres rettigheter. Det blir «empowerment» for barn. - Hvor mye skal barn bestemme? Skal de bli små voksne?

- Barn skal ikke bestemme alt, men de skal alltid bli hørt. Så får man forklare hvorfor de ikke alltid kan få det som de vil.

\section{Veien til Karl Johans gate 7}

- Jeg var et typisk «lærerbarn» og flink på skolen.

Det er ingen leger i familien til Lindboe, men hun visste tidlig hva hun ville. Kropp var spennende. Det var også naturvitenskap, og hun slukte bøker om svartedauden og tuberkulose, Marie Curie og Louis Pasteur.

«Engasjement» er stikkordet fra dem som kjenner henne godt. Hun er interessert i menneskene rundt seg, og nysgjerrig. En MBA (master of business administration) på fritiden er ikke det åpenbare valget når man har full jobb og barn.

- Hvorfor økonomi? 


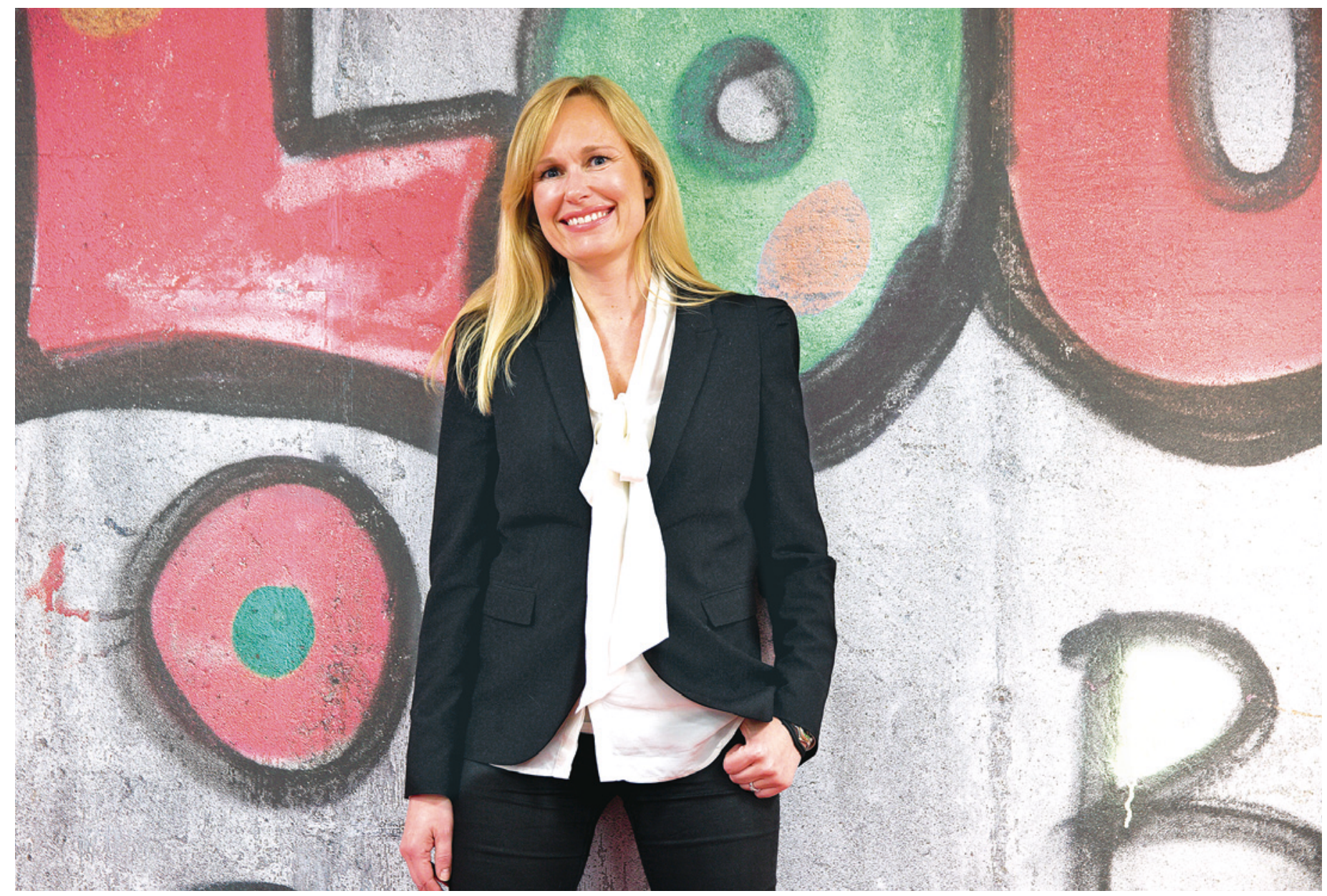

Foto Cornelius Poppe/NTB scanpix

\section{Anne Lindboe}

Født 1. august 1971

- Cand.med. Universitetet i Oslo 2000

- Forsker ved Folkehelseinstituttet/ Rettsmedisinsk institutt

- Spesialist i pediatri 2011

- Master of business administration fra Norges handelshøyskole

- Barneombud 2012-18
- Jeg ville vite mer om hvordan næringslivet fungerer.

- Hvorfor det?

- Økonomi og fag møtes stadig vekk, og da kan det være nyttig å forstå hvordan man leser et budsjett, og ikke minst vite noe om prosesser. Krav om innsparinger møter man overalt $\mathrm{i}$ arbeidslivet. Jeg lærte mye om at A ikke bare fører til B, men har en rekke andre tilsiktede og utilsiktede konsekvenser. Det er ikke bare å sette i gang med en omrokkering. Det har det vært nyttig å kunne i denne jobben. Jeg er jo tross alt administrerende direktør, daglig leder og ansvarlig for både personalet og økonomien. Det er ikke bare i helsevesenet det er knappe budsjetter.

- Er leger for dårlige til å lede?

- Det er ikke påtrengende mange leger som tar lederutdanning. Jeg synes det burde høre med i en topplederstilling i helsevesenet. Sykepleierne har nok vært flinkere til å bygge kompetanse.

\section{Vannkanaler og hybelkaniner}

Det manglet ikke på fete jobbtilbud fra næringslivet med en tung medisinskfaglig bakgrunn og en fersk MBA. Anne Lindboe er selvutnevnt fagidiot.

- Det må man være for å si ja til å være stipendiat på fulltid i stedet for jobb i næringslivet.

- Du er halvveis i en doktorgrad?

- Jobben som barneombud var vel den eneste som kunne fristet meg ut av doktorgradsarbeidet. Den blir tross alt ledig bare hvert sjette år.

- Hva forsket du på?

- Hjerneødemer ved uventet barnedød. Rettsmedisiner Torleiv Rognum er veileder, og arbeidet er tilknyttet Folkehelseinstituttet og gruppen til Ottesen og AmiryMoghaddam ved Senter for molekylærbiologi og nevrovitenskap. - Du var gravid samtidig?

- Det var tøft å obdusere spedbarn og vente et selv. Jeg ble mer nervøs for det tredje barnet når det gjaldt krybbedød. Ved den minste forkjølelse var jeg mye våken om natten frem til hun var ett år.

Lindboe er generelt lite nervøs og har et avslappet forhold til bagateller. Når det stormer på kontoret, kan hun konkludere med at det er ingen som dør. Når hybel- 
kaninene truer med å ta overhånd hjemme, blir hun heller ikke stresset.

- Jeg prøver å sørge for hjemmet tilfredsstiller noen minimumskrav til hygiene, sier hun lattermildt. En journalist var blitt advart om at det ikke var ryddig hjemme hos dem og slo overrasket fast at Lindboe ikke koketterte.

- Vi greier oss uten betalt hjelp hjemme, slår hun fast, før hun kommer på at hun har vaskehjelp hver fjortende dag. - Men vi greier oss ikke uten mye støtte fra familien.

Lindboe og veterinærmannen har tre barn - på tre, åtte og ti år.

- Hvordan synes barna dine det er at du bruker så mye tid på andre barn?

- Det er de for så vidt vant til. Det var ikke annerledes da jeg jobbet på sykehus og hadde vakter på lørdager og julaften. Nå har jeg faktisk fri hver helg og på helligdager. Samtidig er det en del reising, så jeg prioriterer barna mine når jeg har fri. Jeg vil jo ikke sitte der etter seks år som barneombud og ha gått glipp av for mye av barndommen til mine egne barn.

- Hvordan er det å ha en mor som er mye i mediene?

- Halvparten av barna i nabolaget har jo foreldre som er på TV eller i avisen, så jeg tror ikke de synes det er så spesielt.

Lindboe bor i Ullevål hageby, en enklave bestående av kulturkjendiser og den intellektuelle eliten, av andre beskrevet som Bakkebygrenda for barn.

- Hva er det du ikke rekker?

- Jeg trener for lite. Jeg leser nesten ikke skjønnlitteratur. Jeg er en dårlig venninne for tiden. Etter klokken 21 frister sofaen. Man rekker ikke alt, konkluderer hun, uten at hun virker plaget av det. - Jeg synes det fint å vise at det går an å ha både fulltidsjobb og barn. Vi er dessuten to om det. - Synes du det er irriterende at du får spørsmål om barna siden menn ikke får det når de blir intervjuet?

- Nei, jeg skjønner at det er noe mange lurer på. Veldig mange er jo i en skvis uten at de har en profilert stilling. Samtidig tror jeg mange har unødvendig dårlig samvittighet. Barnepsykologen Magne Raundalen uttalte at dagens generasjon foreldre er de beste noensinne. Vi er til stede på en helt annen måte i barnas liv enn generasjonene før oss var - ikke minst er far til stede i større og større grad.

- Hva savner du ved at du ikke jobber som lege?

- Jeg savner pasientene, men jeg er litt kliniker fremdeles. Jeg snakker mye med barn og ungdommer og bruker anamneseopptaket i stor grad fortsatt. Jeg får historiene deres.

Hun savner ikke vaktene, det å vite at du har tretti undersøkelser av små nyfødte barn som venter, men stadig må løpe til noen som er akutt syke. Døgnvakt på sykehus er noe av det mest krevende hun vet om.

- Samtidig er det mye som skal til for å toppe det kicket du får når du redder et lite barn.

Pipet fra vaktcallingen er kanskje det hun savner minst. - Jeg var på fredagsmøtet på Ullevål i dag. Det pep stadig i callingene. Det var deilig å være uten. Det er godt å få tenke en hel tanke uavbrutt.

\section{De stemmeløse}

Lindboe vet godt hvordan det er på sykehus, og nå er hun talerør for små pasienter som ikke kan si sin mening.

- Du har meldt Rikshospitalet til Fylkesmannen?

- Nyfødte på intensivavdeling har også krav på å ha foreldrene hos seg. På Rikshospitalet får du knapt plassert en stol mellom kuvøsene, langt mindre et forheng.

\section{«Vi må ikke være feige når det handler om barn»}

De nyfødte kan ikke rope etter mamma, men tilknytning er utrolig viktig helt fra starten. Det viser seg også at det går bedre med de barna som får være sammen med mor og far. De er mindre stresset.

- Hvordan er det for kollegene at du ber Fylkesmannen se på forholdene? De gjør vel så godt de kan?

- Det giør de, men de er enige og glade for at det blir sagt fra så høyt og tydelig nå. Pasienter og pårørende opplever at leger og sykepleiere strekker seg langt og gjør en fantastisk jobb. Jeg tror det gjør det vanskeligere å klage. Så er det jo ikke jobben jeg klager på, men rammene for de minste barna. Jeg ønsker å påvirke dem som sitter på pengesekken.

- Får du uvenner?

- Det kan jo være at helseforetaksledere i synes det er unødvendig at jeg blander meg i ressursprioriteringen, men det er jobben min. Dette året jobber hele avdelingen med helse. Nå blir det mer penger til helsesøstre, det er jo det faktiske helsetilbudet til mange barn i dag. Det er dessuten et lavterskeltiltak barn og ungdom ønsker seg. De bestiller ikke time hos fastlegen selv. Det er i grunnen helse i alle problemstillinger, enten det dreier seg om mobbing eller asylsøkerbarn.

Barnelegen kommer til syne. - Jeg kan såpass mye om hva som er viktig for barns helse at jeg kan argumentere ganske sterkt for det. Det er også godt å være faglig forankret, vi samarbeider tett med Barnelegeforeningen. Jeg tror det er viktig at noen med grasroterfaring jobber overordnet. Mange ledere er temmelig fjernt fra klinikken.

Lindboe virker utrettelig i sin vilje til å påvirke på barnas vegne.

- Jeg liker så godt utsagnet til Frederick Douglass, født slave, som sa: «Det er lettere å bygge sterke barn enn å reparere ødelagte menn.» Nå bruker Jonas Gahr Støre sitatet også, sier hun og virker litt stolt. - Han brukte det under lanseringen av den nye folkehelsemeldingen.

Hun tar seg nesten i det, men klarer ikke la være. - Hvis du kan skrive noe om meldeplikten, gjentar hun, vel vitende om at hun har sagt det allerede.

Oppfordringen kommer på nytt. Hun klarer ikke slippe tanken på at mange leger kan lese dette. - Husk, det er til legevakten de kommer med skadene sine. Spør hvordan bruddet skjedde. Ikke ta foreldrenes historie for god fisk. Snakk med barnet alene. Ikke glem at syke voksne pasienter også kan ha barn. Spør, spør, spør. Barn forteller meg at de har gått til behandling hos BUP i årevis, og så er det ingen som har spurt om hvordan det er hjemme. Let etter årsaken til diagnoser.

Anne Lindboe snakker mye og fort, og vet det selv. - Rådgiverne bare ler av meg. Jeg starter så langsomt som jeg kan, men så blir jeg revet med, og da tar det ene ordet det andre. Hun slår ut med hendene og trekker litt på skuldrene. - Men det er så mye som er viktig.

Hun koketterer ikke. Hun virker bare genuint engasjert. Det virker som hun bryr seg.

- Hvis jeg kan få noen flere leger til å fange opp barn som trenger hjelp, betyr det så mye.

\section{Marit Tveito}

marit.tveito@me.com

Alderspsykiatrisk avdeling Tåsen

Diakonhjemmet sykehus 